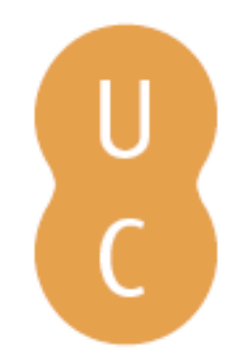

\title{
nommalina
}

\section{Sobre as noções de lógica e de analítica em Kant: algumas dificuldades para o âmbito transcendental}

\author{
Autor(es): Battisti, César Augusto \\ Publicado por: Imprensa da Universidade de Coimbra \\ URL \\ persistente: URI:http://hdl.handle.net/10316.2/38235 \\ DOI: $\quad$ DOI:http://dx.doi.org/10.14195/978-989-26-1049-8_1 \\ Accessed : $\quad$ 26-Apr-2023 12:16:07
}

A navegação consulta e descarregamento dos títulos inseridos nas Bibliotecas Digitais UC Digitalis, UC Pombalina e UC Impactum, pressupõem a aceitação plena e sem reservas dos Termos e Condições de Uso destas Bibliotecas Digitais, disponíveis em https://digitalis.uc.pt/pt-pt/termos.

Conforme exposto nos referidos Termos e Condições de Uso, o descarregamento de títulos de acesso restrito requer uma licença válida de autorização devendo o utilizador aceder ao(s) documento(s) a partir de um endereço de IP da instituição detentora da supramencionada licença.

Ao utilizador é apenas permitido o descarregamento para uso pessoal, pelo que o emprego do(s) título(s) descarregado(s) para outro fim, designadamente comercial, carece de autorização do respetivo autor ou editor da obra.

Na medida em que todas as obras da UC Digitalis se encontram protegidas pelo Código do Direito de Autor e Direitos Conexos e demais legislação aplicável, toda a cópia, parcial ou total, deste documento, nos casos em que é legalmente admitida, deverá conter ou fazer-se acompanhar por este aviso.

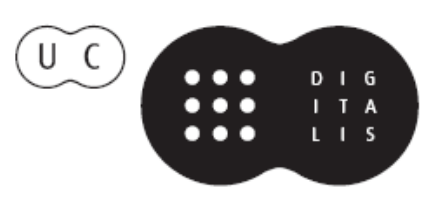



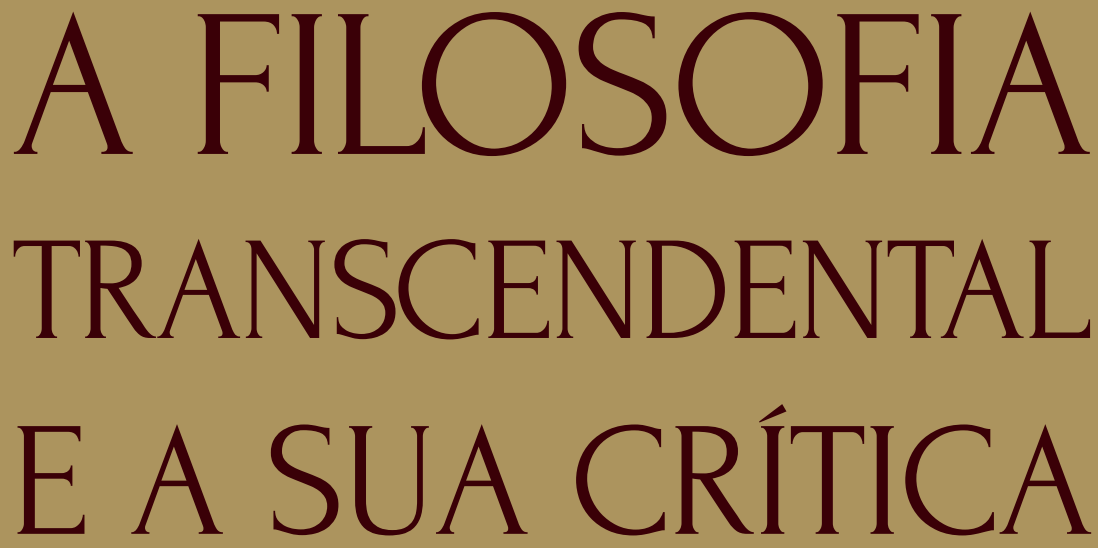

IDEALISMO • FenOMENOLOGIA • HERMENÊUTICA

\author{
DIOGO FERRER \\ LUCIANO UTTEICH \\ (COORDENADORES)
}




\title{
SObRe as NOÇões de lógica E DE ANALÍtica EM KANT:
} Algumas Dificuldades PARA O ÂMBITO TRANSCENDENTAL

\author{
ABOUT THE NOTIONS OF LOGIC AND ANALYTIC IN KANT: \\ SOME DifFICULTIES FOR THE TRANSCENDENTAL RANGE
}

César Augusto Battisti*

(UNIOESTE - Universidade Estadual do Oeste do Paraná)

\begin{abstract}
This Chapter examines the notions of logic and analytic in The Critique of Pure Reason by Immanuel Kant, especially in the Analytic of Concepts. It starts from a comparison between The Logic and The Critique and shows a double influence of the first upon the second: in the range of the structure of both works and in the range of logic and analytic conception. The first emerging difficulty is that this influence occurs both on The Critique in its totality and on the Transcendental Logic. The second difficulty is that the transcendental analytic, inspired by the logic analytic,
\end{abstract}

\footnotetext{
*cesar.battisti@hotmail.com

César Augusto Battisti, natural de Lajeado - RS, Brasil, é doutor em Filosofia pela Universidade de São Paulo (2000), tendo realizado nesse período estágio doutoral na Université Paris 7 junto à Equipe REHSEIS (Recherches Épistemologiques et Historiques sur les Sciences Exactes et les Institutions Scientifiques). Professor da Universidade Estadual do Oeste do Paraná (UNIOESTE) atua nos seus Cursos de Graduação e de Pós-Graduação em Filosofia, e se dedica a estudos nas áreas de filosofia moderna, epistemologia e história da ciência, tendo publicado o livro O Método de Análise em Descartes: Da Resolução de Problemas à Constituição do Sistema do Conhecimento (Edunioeste, 2002), a tradução do tratado O Mundo, de René Descartes (Editora da Unicamp, 2009), além de capítulos de livros e artigos em periódicos especializados.
} 
characterizing itself as dissection and as dissection of concepts on its formal aspect, cannot accomplish its transcendental function, reason why it needs to be assisted by a synthesis. Both procedures, however, are not absolutely sympathetic, since the analytic, remaining formal, as vestige of the logic analytic influence, implies neither the synthesis nor the transcendental range properly speaking. The core of the Analytic of Concepts seems to be far more a "synthetic of concepts" than an analytic of concepts.

Keywords: Kant; Transcendental Logic; Analysis - Synthesis; Dissection of Concepts

Resumo: Este capítulo examina as noções de lógica e de analítica na Crítica da Razão Pura de Immanuel Kant, especialmente na Analítica dos Conceitos. Ele parte de uma comparação entre a Lógica e a Crítica e mostra uma dupla influência da primeira sobre a segunda: no âmbito da estrutura das duas obras e no âmbito da concepção de lógica e de analítica. A primeira dificuldade daí emergente é que essa influência se dá tanto sobre a Crítica em sua totalidade quanto sobre a Lógica Transcendental. A segunda dificuldade é que a analítica transcendental, inspirada na analítica lógica, se caracterizando como decomposição e como decomposição de conceitos sob seu aspecto formal, não consegue cumprir sua função transcendental, razão pela qual precisa ser socorrida por uma síntese. Os dois procedimentos, contudo, não são absolutamente solidários, visto que a analítica, se mantendo formal, como resquício da influência da analítica lógica, não implica a síntese nem o âmbito transcendental propriamente dito. O núcleo da Analítica dos Conceitos parece ser muito mais uma "sintética dos conceitos" do que uma analítica dos conceitos.

Palavras-Chave: Kant; Lógica Transcendental; Análise - Síntese; Decomposição de Conceitos 
A Crítica da Razão Pura possui uma estrutura e uma dinâmica interna de inspiração lógica. Essa é a tese a que chegamos tão logo a comparamos com o Manual dos Cursos de Lógica ${ }^{1}$, texto organizado, a pedido e sob a supervisão de Kant, por Jäsche, a partir dos cursos de lógica que o filósofo ministrara ao longo de seus anos de docência. As duas obras contêm partes similares e correspondentes, tanto em seus aspectos ou traços gerais quanto em suas subdivisões e considerações mais particulares. A mesma conclusão parece poder ser extraída das inúmeras vezes em que Kant, na Crítica, estabelece comparações entre a lógica geral e a lógica transcendental, a tal ponto que a segunda parece ser compreendida a partir de parâmetros estabelecidos pela primeira e a partir de semelhanças e diferenças entre elas ${ }^{2}$.

Comecemos por esse último ponto. Na Crítica, Kant consagra toda a Introdução à Lógica Transcendental a uma comparação e distinção entre lógica geral e lógica transcendental, bem como entre as respectivas divisões entre analítica e dialética ${ }^{3}$. O objetivo é compreender essa nova lógica, inaugurada por ele. E, apesar desse termo inovador - transcendental -, trata-se aí, ainda assim, de uma lógica, e sua compreensão passa por uma aproximação à lógica geral. Nesse sentido, a Introdução recupera reflexões já contidas na Lógica, quanto às divisões, definições

\footnotetext{
${ }^{1}$ Os títulos dessas duas obras serão abreviados, respectivamente, como Crítica e como Lógica. As citações terão como referências a paginação das edições A e B, para a Crítica, e da edição da Academia (AK, vol. IX), para a Lógica, embora sejam utilizadas as traduções existentes em língua portuguesa. Tais referências, ao contrário das outras, em razão da frequência com que se sucedem, serão feitas no interior do texto, em seguida ao próprio trecho citado.

${ }^{2}$ Howard Caygill, no Dicionário Kant (2000), 218-219 (verbete "lógica geral/transcendental"), vai mais longe e afirma que toda a obra de Kant, em seu conjunto, pode "ser considerada uma vasta meditação sobre lógica", a começar pelas três críticas.

${ }^{3}$ A distinção entre as duas lógicas, geral e transcendental, embora feita rapidamente, já se encontra na Lógica (AK15).
} 
e caracterizações da lógica geral, e as examina no âmbito da lógica transcendental ${ }^{4}$. Na sequência, em especial ao longo da Analítica ${ }^{5}$, é constante a comparação entre as duas lógicas, tanto para a discussão de temas específicos, como quando Kant está montando a tábua dos juízos e a das categorias, quanto para considerações mais gerais, como quando quer deixar clara a diferença entre as duas perspectivas ou a (im)possibilidade de a transcendental imitar a geral 6 .

Tampouco há dúvida sobre a origem lógica da distinção entre analítica e dialética, ainda que haja incongruências entre as duas lógicas quanto às questões que envolvem essa divisão. A Lógica a afirma claramente ${ }^{7}$, ao mesmo tempo em que a remete à história da disciplina até Aristóteles ${ }^{8}$. E, da mesma forma que, no âmbito lógico, essa divisão se pauta pela divisão das "faculdades superiores do conhecimento" em entendimento, capacidade de julgar e razão, às

\footnotetext{
4 A Introdução, cujo título é "Ideia de uma lógica transcendental", contém quatro seções, as quais são elucidativas do tema em discussão. São elas: "I. Da lógica em geral"; "II. Da lógica transcendental"; "III. Da divisão da lógica geral em analítica e dialética"; "IV. Da divisão da lógica transcendental em analítica e dialética transcendentais" (A50-64/B74-88).

${ }^{5}$ É abundante o uso da expressão "lógica geral", em comparação à transcendental, nesta parte da Crítica.

${ }^{6}$ Em vários momentos, Kant reconhece, ou a impossibilidade de a lógica transcendental imitar a geral, ou seu distanciamento em relação à lógica geral. Ver, por exemplo, a Terceira Secção (§ 10) do Capítulo I da Analítica dos Conceitos (B102-105), em especial a forma oposta de avaliação das duas lógicas: "A lógica geral abstrai, como repetidas vezes dissemos, de todo o conteúdo do conhecimento e espera que, por outra via [...]. Em contrapartida, a lógica transcendental defronta-se com [...]." (A76/B102); "Diversas representações são reduzidas, analiticamente, a um conceito (questão de que trata a lógica geral). Mas a lógica transcendental ensina-nos a reduzir a conceitos, não as representações, mas a sintese pura das representações" (A78 / B104); “O mesmo entendimento, pois, [...] introduz também [...] um conteúdo transcendental nas suas representações do diverso; por esse motivo se dá a estas representações o nome de conceitos puros do entendimento, que se referem a priori aos objetos, o que não é do alcance da lógica geral" (A79/B105). Veja também os primeiros parágrafos da Analítica dos Princípios (A131/B170), dos quais alguns trechos são citados mais adiante.

7 Diz a Lógica: "A Lógica divide-se em: 1) Analítica e Dialética" (AK16).

8 Afirma o texto: “A Lógica atual descende da Analítica de Aristóteles. Esse filósofo pode ser considerado o pai da Lógica. Ele a expôs como órganon e a dividiu em Analítica e Dialética" (AK20).
} 
quais correspondem as funções do conceito, do juízo e da inferência ${ }^{9}$, a lógica transcendental, de sua parte, se baseia nessa divisão e se guia por ela, embora tenha uma configuração própria em razão de seus propósitos e de suas características e, por isso, em seu percurso dela se distancie ${ }^{10}$. Nesse sentido, a cada analítica corresponderá também uma lógica da verdade e, a cada dialética ${ }^{11}$, uma lógica da aparência e sua dissolução ou crítica ${ }^{12}$. E, assim, a todo momento, as duas lógicas se medem uma pela outra: a esse respeito, são esclarecedoras as introduções das diferentes partes e dos diferentes capítulos da Lógica Transcendental. A conclusão que extraímos dessas considerações é a de que a lógica transcendental é o espelhamento, tanto quanto possível, da lógica geral.

O curioso, entretanto, é que esse espelhamento, antes de ser entre as lógicas, se dá entre as próprias obras como um todo, a Lógica e a Crítica, e, portanto, entre lógica geral e crítica da razão (pura), algo de alcance bem mais amplo que o anterior. Com efeito, se a Crítica se

${ }^{9}$ Sobre a divisão entre intelecto, faculdade judicativa e razão, bem como entre conceitos, juízos e ilações, cf. o Sumário da Lógica.

10 Diz a Crítica no início da Analítica dos Princípios: "A lógica geral está edificada sobre um plano que se ajusta exatamente à divisão das faculdades superiores do conhecimento. São estas o entendimento, a faculdade de julgar e a razão. Essa doutrina trata, pois, na sua analítica, de conceitos, juízos e raciocínios, em conformidade com as funções / e a ordem dessas faculdades do espírito, compreendidas sob a denominação lata de entendimento em geral" (A130-131/B169). Neste caso específico, a lógica transcendental não pode segui-la: "A lógica transcendental, que se restringe a um conteúdo determinado, ao dos simples conhecimentos puros a priori, não pode imitá-la nessa divisão. Com efeito, dado que o uso transcendental da razão não é válido objetivamente, não pertence, portanto, à lógica da verdade, ou seja, à analítica; antes requer, como lógica da aparência, uma parte especial da doutrina escolástica, denominada dialética transcendental" (A131/B170).

11 Sobre a divisão da lógica em analítica e dialética e sobre a caracterização delas, respectivamente, como lógicas da verdade e da aparência, cf. a Lógica (AK16-17). Na Crítica, essa caracterização aparece principalmente nos locais de comparação entre as duas lógicas (p. ex., em A60-63/B84-88 e em A131/B170).

12 A ilusão lógica pode desaparecer e, portanto, cessar de ser uma ilusão, ao passo que a ilusão transcendental "nunca alcançará que essa aparência desapareça (como a aparência lógica) e deixe de ser aparência", por se tratar de uma "ilusão natural e inevitável" (A297-98/B354). 
divide em uma doutrina dos elementos e uma doutrina do método, ela o faz a partir dessa divisão presente na Lógica. Afirma Kant: "a Lógica teria, portanto, uma parte dogmática e uma parte técnica. A primeira poderia chamar-se Doutrina dos Elementos, e a segunda, Doutrina do Método" (AK18). Como se pode ver claramente no seu Sumário, a Lógica se compõe exatamente dessas duas partes ${ }^{13}$, de uma Doutrina Geral dos Elementos e de uma Doutrina Geral do Método, divisão imitada pela Crítica, mesmo que, desta vez, a origem não se remonte apenas à tradição aristotélica, mas à confluência de duas tradições, a aristotélica e a "moderna"14.

Com efeito, por um lado, "a Lógica descende da Analítica de Aristóteles", o "pai da Lógica", que a "dividiu em Analítica e Dialética" (AK20). Depois dele, a disciplina permanecera, segundo Kant, quase inalterada ${ }^{15}$. A Crítica, ao seguir a Lógica, na sua Doutrina Transcendental dos Elementos (mais exatamente, na sua Lógica Transcendental), segue de perto a tradição aristotélica, na medida em que esta analisa seu objeto a partir de seus três componentes básicos, o conceito/termo, o juízo/proposição e o raciocínio/inferência ${ }^{16}$. Por outro lado, ainda que de origem lógica, a Doutrina do Método não se apresenta claramente configurada na obra aristotélica, mas está explicitamente posta pela

\footnotetext{
${ }^{13}$ Embora contenha, é verdade, uma longa Introdução que poderia corresponder a uma terceira parte.

14 Sobre essa confluência, cf. Caygill (2000), 219, dentre outros.

${ }^{15}$ Diz Kant: “De resto, quanto ao seu conteúdo, não foi muito o que a Lógica ganhou desde a época de Aristóteles e não o poderia, em razão de sua natureza" (AK20). Ver também, na Crítica, o Prefácio à edição B (Bviii).

16 Afirma Charles Jourdain, em nota à publicação de La Logique ou l'Art de Penser, relativa às três primeiras das quatro principais operações do espírito, conceber, julgar, raciocinar e ordenar (ver também nota a seguir): “O primeiro gênero dessa divisão parece se encontrar em Aristóteles, que trata, com efeito, das ideias no livro das Categorias, que são a primeira parte do Órganon, dos juízos e das proposições, no tratado Da Interpretação, do raciocínio nos Primeiros e nos Segundos Analíticos" (Arnault e Nicole (1992), n. 13, 337; tradução nossa). Podemos ver, entretanto, esses elementos diretamente nas primeiras páginas dos Primeiros Analíticos, quando Aristóteles define o que entende por termo (ideia), premissa e proposição e por silogismo.
} 
tradição inaugurada pela Lógica de Port-Royal, com a obra A Lógica ou a Arte de Pensar, de A. Arnault e P. Nicole. A modificação estrutural mais substancial dessa última é, exatamente, a introdução da doutrina do método como quarta parte da lógica, depois das outras três, de inspiração aristotélica, correspondentes aos três atos intelectuais relativos aos elementos indicados acima: com a introdução dessa parte concernente exatamente ao método, às quatro partes corresponderão as quatro principais operações do espírito: conceber, julgar, raciocinar e ordenar ${ }^{17}$. Assim, ainda que sob a perspectiva aristotélica certamente não coubesse incluir na lógica um tratado sobre o método (e sua função de ordenar), segundo a concepção discutida aqui ${ }^{18}$, é plenamente justificável a sua inclusão a partir da perspectiva moderna. É isso que a Lógica faz e, por extensão e imitação, também a Crítica.

A segunda modificação importante introduzida pela perspectiva moderna diz respeito ao escopo da lógica: contrariamente à perspectiva aristotélica, a lógica moderna (de inspiração cartesiana) está menos interessada na análise das formas de inferências válidas do que na produção de juízos sadios e verdadeiros. A lógica moderna é menos formal ${ }^{19}$ do que a aristotélica, embora Kant preserve o caráter for-

17 Confira: "A lógica é a arte de bem conduzir a própria razão no conhecimento das coisas, tanto para se instruir a si mesmo quanto para instruir os outros. Esta arte consiste nas reflexões que os homens fizeram sobre as quatro operações de seu espírito: conceber, julgar, raciocinar e ordenar" (Arnault e Nicole (1992), 30; tradução nossa).

18 Talvez se pudesse buscar no Órganon um quadro teórico correspondente a uma doutrina do método desse tipo.

${ }^{19}$ Confira a nota acima, onde a lógica é definida como a arte de bem conduzir a razão no conhecimento das coisas. Em seguida a esse texto, Arnault e Nicole afirmam que as operações estudadas pela lógica se fazem naturalmente e "por vezes melhor por aqueles que não aprenderam nenhuma regra de lógica", visto que "a só natureza nô-las fornece ao nos dar a razão". Assim, a lógica tem três funções: bem utilizar a razão; descobrir e explicar o erro e os defeitos que podem ocorrer nas operações do espírito; conhecer melhor a natureza de nosso espírito (Arnault e Nicole (1992), 30-31; tradução nossa). Bem se vê o espírito de Descartes aí presente, ele que pouca importância atribuía à lógica (ou a via como prejudicial, mais do que imprescindível): cf. o subtítulo do Discurso do Método: "Para bem conduzir a própria razão e procurar a verdade nas ciências" (Descartes (1983), 25). 
mal na lógica geral, neste aspecto seguindo a concepção aristotélica. A Lógica Transcendental, mesmo que não possa nisso imitá-la ${ }^{20}$, por não ser nem geral nem formal ${ }^{21}$, parece se aproximar da perspectiva da lógica moderna. A Crítica, assim, radicaliza a influência dos modernos, quando comparada à Lógica; e, sob esse aspecto, pode reivindicar a pretensão de conter, verdadeiramente, em sua analítica, uma lógica da verdade, ao passo que a lógica geral continha uma lógica da verdade apenas em sentido negativo (A60-63/B84-88 e em A131/B170) ${ }^{22}$. Ora, a passagem de uma analítica como lógica da verdade em sentido negativo para uma lógica da verdade em sentido positivo parece ter sido sugerida pela nova lógica, na medida em que ela incorpora, em seu exame, a materialidade do conhecimento; com isso, ela não consegue conservar nem o caráter formal nem o caráter geral ${ }^{23}$ da

\footnotetext{
20 Veja-se, por exemplo, o início da Analítica dos Princípios e as citações correspondentes dadas mais acima.

${ }^{21}$ Esse tema será retomado mais adiante. De todo modo, Kant é bastante claro em várias ocasiões sobre o caráter particular e material da lógica transcendental, como no início tanto da Analítica dos Princípios quanto da Doutrina Transcendental do Método: "A lógica transcendental, que se restringe a um conteúdo determinado, ao dos simples conhecimentos puros a priori, não pode imitá-la nessa divisão." (A131/B170); "Se considerar o conjunto de todo o conhecimento da razão pura e especulativa como um edifício, de que temos em nós pelo menos a ideia, poderei dizer que, na doutrina transcendental dos elementos, avaliamos os materiais e determinamos para que tipo de edifício, altura e solidez seriam suficientes." (A707/B735); "Entendo assim por doutrina transcendental do método a determinação das condições formais de um sistema completo da razão pura." (A708/B736; itálicos todos nossos). Embora nessas últimas citações a contraposição se dê entre as duas doutrinas (dos elementos e do método) e embora, na Doutrina dos Elementos, a materialidade da Estética seja mais evidente, as outras citações confirmam suficientemente a da Lógica Transcendental. Afinal, esta última faz parte de uma doutrina dos elementos, dos materiais que compõem o conhecimento. De sua parte, a Dialética tem seus maiores problemas oriundos exatamente da falta de materialidade e do "desejo ardoroso" de tê-la.

22 A lógica geral é apenas uma lógica da verdade em sentido negativo, exatamente porque é formal, isto é, porque preenche apenas as condições formais da verdade, mas não sua materialidade: "Como, porém, a simples forma do conhecimento, por mais que concorde com as leis lógicas, é de longe insuficiente para constituir a verdade material (objetiva) do conhecimento, ninguém pode atrever-se a ajuizar dos objetos apenas mediante a lógica" (A60/B85).

23 A lógica transcendental não é nem geral nem formal, e distinguir-se da lógica geral é um dos intentos da Introdução à Lógica Transcendental. Enquanto, na lógica transcendental, "o próprio objeto é representado como um objeto só do intelecto", a
} 
lógica, embora - e aí se localiza a tensão - conserve a noção de analítica lógica, de inspiração aristotélica.

E, portanto, a natureza lógica da Crítica pode ser vista tanto a partir de sua totalidade quanto a partir de uma de suas partes, a Lógica Transcendental. Isso, entretanto, gera determinadas incongruências entre as obras e certas tensões entre as duas concepções de lógica (e de analítica).

Com efeito, enquanto a divisão entre doutrina dos elementos e doutrina do método, na Lógica, é uma divisão também da própria lógica $^{24}$, na Crítica isso não ocorre, visto que, nesta, a lógica (transcendental) é que é parte da doutrina dos elementos, contrariamente ao que acontece naquela obra, onde é a doutrina dos elementos que é parte da lógica (geral). Se, por um lado, a estrutura da Crítica segue a estrutura da Lógica, a lógica transcendental, por outro, já não pode seguir, nesse quesito, a lógica geral. E, portanto, enquanto na Lógica o conjunto das duas doutrinas (dos elementos e do método) e a lógica são coextensivas, na Crítica, as duas doutrinas excedem duplamente o âmbito da lógica, seja porque a doutrina dos elementos é mais ampla que a lógica transcendental (esta sendo parte daquela), seja porque a doutrina do método se encontra totalmente excluída desta última. Não sendo coextensivas a lógica transcendental e a Crítica, contrariamente à correspondente coextensão entre lógica geral e Lógica, parece

\footnotetext{
lógica geral, como o nome já diz, "trata de todos os objetos em geral" (AK15) e, para tal, deve ser absolutamente formal: "A lógica geral abstrai, como indicamos, de todo o conteúdo do conhecimento, ou seja, de toda a relação deste ao objeto e considera apenas a forma lógica na relação dos conhecimentos entre si, isto é, a forma do pensamento em geral"; "a lógica geral trata, por conseguinte, apenas da forma do entendimento que pode ser dada às representações, qualquer que seja a sua origem" (A55-56/B79-80). A lógica transcendental, por sua vez, "trata das leis do entendimento e da razão, mas só na medida em que / se refere a objetos a priori e não, como a lógica vulgar, indistintamente aos conhecimentos de razão, quer empíricos quer puros" (A57/B81-82). Ela, exatamente, é "mal usada" dentro de um "uso geral e ilimitado" e "constitui atrevimento julgar, afirmar e decidir sinteticamente sobre objetos em geral, utilizando somente o entendimento puro" (A63/B88).

${ }^{24}$ Diz a Lógica (AK18): "Segundo essa divisão, a Lógica teria, pois, uma parte dogmática e uma parte técnica. A primeira poderia chamar-se Doutrina dos Elementos, e a segunda, Doutrina do Método".
} 
inevitável a dissociação de elementos originalmente ligados e a ocorrência de certos desajustes em uma estrutura pretensamente unitária ${ }^{25}$.

Essas considerações só reforçam a inspiração de natureza lógica da estrutura da Crítica, ao mesmo tempo em que evidenciam as dificuldades da adequação dessa estrutura a uma nova dimensão, a do transcendental: a Crítica parece se rebelar, aqui e acolá, contra as amarras de uma disciplina que é de ordem e alcance geral e formal, visto que a lógica transcendental diz respeito a algo cuja natureza é de ordem "material" 26. Schopenhauer talvez tenha sido o filósofo que mais se queixou desse gosto kantiano exacerbado pelo enquadramento das "coisas" à estrutura, pelas distinções simétricas e pela excessiva repetição das divisões sincronizadas e subordinadas, pela mania kantiana de submeter tudo a um ordenamento de natureza formal e de querer construir a todo custo um "sistema completo da

25 Tanto a Crítica quanto a Lógica (e, por equivalência, a lógica geral) possuem uma Doutrina dos Elementos e uma Doutrina do Método, contrariamente à lógica transcendental que é apenas parte da Doutrina Transcendental dos Elementos. Na Lógica, a doutrina dos elementos é parte da lógica; na Crítica, a lógica é parte da doutrina dos elementos. As diferenças mais gerais da Crítica em relação à Lógica são, portanto, duas: encontram-se excluídas da lógica (transcendental), mas não da Crítica, a doutrina do método e parte da doutrina dos elementos, enquanto estas duas partes fazem parte da Lógica e, portanto, da lógica geral; não é mais a doutrina dos elementos que é a primeira parte da lógica (como ocorre na Lógica), mas é a lógica (transcendental) que é parte da doutrina dos elementos, o que equivale a dizer que há elementos que se encontram excluídos da abrangência da lógica transcendental.

${ }^{26}$ Afirma a Lógica: “Em todo conceito, devem-se distinguir matéria e forma. A matéria dos conceitos é o objeto; sua forma, a universalidade" (AK91). É verdade que a Lógica Transcendental se caracteriza como formal e se contrapõe à materialidade da Estética, na medida em que esta fornece a matéria do conhecimento. A divisão entre matéria e forma, contudo, é sempre relativa ao local em que está sendo feita, de sorte que o que era matéria no estágio anterior pode, em seguida, ser desmembrado em matéria e forma. Assim, na Estética procede-se a uma equivalente divisão entre matéria (sensação) e forma (formas puras da sensibilidade), bem como em relação a noções como a de fenômeno (matéria e forma do fenômeno) (A20/B34). Matéria e forma são termos correlativos mesmo na lógica geral, e valem, por exemplo, tanto para conceitos quanto para juízos. Ademais, o próprio Kant diz, com Aristóteles, que a pura matéria é plena indeterminação ("intuições sem conceitos são cegas") e a pura forma é vazio absoluto ("pensamentos sem conteúdo são vazios") (A51/B75). Assim, sempre que há determinação de algo, há matéria e forma, visto que determinar algo é atribuir uma forma a alguma matéria ou coisa. 
razão pura" (A708/B736): trata-se, diria Schopenhauer, de um excesso de "amor pela simetria arquitetônica" 27 . Esse exagero no estabelecimento de simetrias no interior da obra (exemplificadas, por exemplo, pelas diferentes tábuas e seus desdobramentos ao longo da Analítica e da Dialética) se origina, parece-nos, dessa dupla (as)simetria, mais fundamental e contagiante, apontada mais acima: 1) entre a Lógica/ lógica geral e a Crítica; e 2) entre lógica geral e lógica transcendental. Essa tensão presente no pensamento kantiano será examinada abaixo, particularmente a partir da noção de analítica, e se restringirá à Analítica dos Conceitos.

As noções de análise e de analítica podem ser classificadas em Kant dentro de cinco ou seis perspectivas, todas elas, de alguma forma, relacionadas e, portanto, passíveis de aglutinação ou de desmembramento. Tais noções aparecem: 1) na distinção entre juízos analíticos e juízos sintéticos; 2) na distinção entre analítica e dialética como partes da lógica; 3) na distinção entre método da análise e método da síntese de origem geométrica; 4) na distinção entre os sentidos lógicos de análise e de síntese, entendidas respectivamente como decomposição/resolução e composição/ligação; 5) na distinção entre análise e síntese como funções ou resultado de ações do entendimento; 6) na distinção entre unidade analítica e unidade sintética da consciência.

Embora alguns desses significados sejam originalmente kantia$\operatorname{nos}^{28}$, de um modo geral podemos afirmar que as noções de análise e de analítica têm uma longa e complexa história desde os gregos. Tais termos, além de seus usos na linguagem comum, já apareciam

\footnotetext{
27 Schopenhauer (1988), 112.

${ }^{28}$ Seria possível relativizar a originalidade deste ou daquele conceito kantiano por meio de suas antecipações parciais ou funções equivalentes.
} 
na mitologia ${ }^{29}$ e receberam vários sentidos nas filosofias dos antigos. O uso que deles faz Aristóteles, para além da divisão entre analítica e dialética ${ }^{30}$, pode ser aglutinado ao redor de dois sentidos básicos - 1) como decomposição de uma totalidade em seus elementos e 2) como regressão ou recondução a algo mais básico ou a um princípio -, configurando, dessa forma, as duas grandes tradições influentes ao longo de mais de dois séculos, a da própria analítica aristotélica e a dos geômetras gregos, praticantes da análise geométrica ${ }^{31}$. Aristóteles, em sua silogística, faz uso predominantemente da primeira acepção, quando o silogismo é desmembrado e examinado quanto a seus elementos componentes, suas diferentes configurações e recondução à figura mais perfeita, embora apresente considerações sobre o método geométrico $^{32}$ e embora muitos de seus usos possam ser interpretados como atinentes seja a um seja a outro dos dois sentidos.

De todo modo, são duas as acepções paradigmáticas em Aristóteles e na tradição, cuja história se encarrega de fazer tanto aproximações

${ }^{29}$ Assim, na Odisseia, Penélope, enquanto esperava o retorno de Ulisses, tecia o manto durante o dia e o desfazia à noite, ela "o compunha de dia e o analisava à noite" (apud Timmermans (1995), 1-2).

30 Veja-se, por exemplo, nos Segundos Analíticos de Aristóteles (1992-1995), I, 22. 84 a8-10: "Do ponto de vista dialético, as provas que acabamos de apresentar são suficientes para produzir no sujeito a convicção disso que afirmamos. Mas uma prova analítica mostrará mais brevemente ainda que nem a série ascendente nem a série descendente dos predicados seria infinita em número, nas ciências demonstrativas que são o objeto de nossa pesquisa". Cf. tb. Aristóteles (1992-1995), I, 21. 82 a35.

${ }^{31}$ Aqui os intérpretes se dividem em exacerbar a diferença ou aproximar as duas tradições, tanto na época de Aristóteles quanto nos períodos posteriores. Há autores que estabelecem exatamente o pensamento kantiano como o fechamento desse ciclo de influências e de entrecruzamento das duas tradições no pensamento filosófico ocidental. Ver, a respeito, Timmermans (1995), Hintikka e Remes (1973; 1974), Loparic (1982), dentre outros.

32 Cf. o que Aristóteles afirma na Ética a Nicômaco (1987), 46: “Com efeito, a pessoa que delibera parece investigar e analisar da maneira que descrevemos, como se analisasse uma construção geométrica (nem toda investigação é deliberação: vejam-se, por exemplo, as investigações matemáticas; mas toda deliberação é investigação); e o que vem em último lugar na ordem da análise parece ser primeiro na ordem da geração. E se chegamos a uma impossibilidade, renunciamos à busca: por exemplo, se precisamos de dinheiro e não há maneira de consegui-lo; mas se uma coisa parece possível, tratamos de fazê-la". 
e fusões quanto distanciamentos e desvinculações ${ }^{33}$. Ainda que o termo analysis signifique fundamentalmente resolução (traduzido para o latim por resolutio) e contenha como matriz a ideia de que os elementos básicos apontados por ela sejam constituintes da totalidade examinada e do seu processo de inteligibilidade, na acepção geométrica, contrariamente à acepção lógica, a análise é menos a indicação por separação ou dissecação dos elementos componentes do que a busca de objetos ou relações fundamentais que possibilitam a determinação e compreensão do complexo originalmente dado. Como tal, na análise geométrica, a compreensão dos elementos componentes pressupõe a preservação, neles, da função que exercem na compreensão da totalidade $^{34}$. Por isso, nessa acepção é a noção de regressão ${ }^{35}$ que é mais central, regressão a algo determinante da configuração considerada, cuja "natureza" ou identidade pressupõe a preservação dessa sua função ${ }^{36}$. A análise geométrica tem um sentido mais forte de subida, de movimento para cima ou, mesmo, de recondução a algo que contém a chave, o segredo do que está em jogo, e o que está em jogo deve ser compreendido exatamente a partir da configuração dada ${ }^{37}$.

É verdade que ambas as análises são um procedimento na direção dos princípios, para algo anterior, primário e mais alto (se assumirmos

${ }^{33}$ E. Berti (2000), 118-119, parece não concordar com essa redução a dois significados básicos.

${ }^{34}$ Além disso, na análise geométrica, não é necessário que os componentes sejam, rigorosamente, elementos nem que sejam, necessariamente, mais simples. A simplicidade se dá muito mais em razão da função que o elemento componente exerce na totalidade e do caráter de determinação entre ele e a configuração geral.

${ }^{35}$ Essa é também a concepção kantiana da análise e da síntese de origem geométrica: "O método analítico opõe-se ao sintético. O primeiro começa do condicionado e do fundamentado e dali progride até os princípios. O segundo, ao oposto, vai dos princípios aos conseqüentes ou do simples ao composto. O primeiro pode ser denominado também de método regressivo, e o segundo, de método progressivo" (AK149).

${ }^{36}$ Aí, um elemento atomizado não é apenas um átomo, mas ele em sua articulação molecular.

37 Note-se que Kant não se esforça, na Analítica Transcendental, pelo menos de forma explícita, para estabelecer relações de aproximação conceitual entre a analítica, definida como decomposição, e a análise entendida como regressão. 
que os princípios se situam acima daquilo que deles depende), algo indicado claramente pelo prefixo da palavra "análise". ${ }^{38}$ No sentido aristotélico, entretanto, a regressão aos elementos simples tem o sentido de decomposição e de que o composto é originado a partir desses elementos por reunião ou justaposição. Por isso, nesse sentido lógico do termo, a análise não precisa de uma síntese, cuja razão, neste caso, é que seus elementos constituintes se configuram individualmente como entidades completas e com suficiente autonomia, embora integrantes de uma totalidade. No sentido geométrico, os "componentes" descobertos precisam de uma determinação posterior, fornecida pela síntese ${ }^{39}$, em razão do fato de que não se pode garantir, pela análise, que eles estejam dados e sejam efetivamente reais. Além disso, a análise geométrica, no caso específico dos gregos pelo menos, é feita sobre uma configuração particular, sendo, portanto, menos formal e menos geral que a analítica aristotélica: a análise geométrica não se pauta por esquemas lógicos, mas por uma análise das relações concretamente dadas, e seus resultados (sua solução) são válidos, em princípio, apenas para a configuração particular dada. Ela resolve o problema da inteligibilidade de uma configuração particular; e, por isso, é um método de descoberta e de resolução de problemas. Seus elementos constituintes não são, portanto, "elementos-entidade", mas "elementos-relações" da resolubilidade da complexidade proposta. A inexistência da síntese na analítica aristotélica, ao contrário, denuncia a autonomia e a possibilidade de atomização dos elementos encontrados na decomposição lógica ${ }^{40}$.

Agora, voltando aos diferentes sentidos da análise e de analítica encontrados em Kant, três deles (o primeiro e os últimos dois) efe-

38 Como chama a atenção Berti (2010), 119, o prefixo "aná" indica justamente a direção para cima.

${ }^{39} \mathrm{Ou}$ por outra operação acoplada à análise, como a intuição (cartesiana).

${ }^{40}$ Historicamente, há casos em que a etapa sintética complementar à análise geométrica não era necessária ou era dispensável. E isso por razões distintas, tais como quando os passos analíticos e sintéticos eram reversíveis (constituírem-se em equivalências) ou quando os passos analíticos se baseiam em algo como "apreensões intuitivas". 
tivamente se cristalizam no interior da filosofia kantiana - aquele concernente à distinção entre juízos analíticos e juízos sintéticos, aquele que diz respeito à análise e à síntese como ações do entendimento, e aquele relativo às unidades analítica e sintética da consciência - ao passo que os outros três pertencem à tradição filosófica desde os gregos. Dentre todos, apenas o segundo (que trata da divisão entre analítica e dialética) não trabalha com a oposição entre análise e síntese. E é essa última oposição que mais nos interessa mais adiante, tendo em conta as considerações feitas acima sobre a natureza lógica da Crítica.

\section{III}

A Lógica já opera com a oposição entre análise e síntese, e a distinção entre elas se dá a partir de diferentes perspectivas, dentre as quais se destacam vários tipos de "operações" analíticas e sintéticas, além da distinção entre proposições analíticas e proposições sintéticas.

Um primeiro conjunto de considerações dentro desse quadro de oposição entre análise e síntese, operado na Lógica, ocorre quando Kant caracteriza o conhecimento discursivo ou conceitual como constituído por "notas" e as distingue entre notas analíticas e notas sintéticas (AK58-59). Segundo Kant, "o conhecimento ocorre por notas" e "só conhecemos as coisas por notas", sendo uma nota "o que constitui, numa coisa, uma parte de seu conhecimento", "uma representação parcial, considerada fundamento do conhecimento de uma representação total" (AK58). As notas podem ter um uso interno (derivativo) e um uso externo (comparativo); elas podem ser coordenadas por justaposição (cuja agregação dá a totalidade de um conceito) ou se ligarem por subordinação (dando origem a uma série conceitual). A agregação de notas coordenativas permite, pela síntese, o crescimento da distinção extensiva ou ampliativa do conceito, ao passo que as notas subordinativas permitem, pela análise, o crescimento da distinção intensiva ou profunda (AK59). Em razão disso, as notas analíticas são conceitos 
parciais da totalidade de um conceito efetivamente real ou dado, enquanto as sintéticas o são de um conceito meramente possível, sendo ampliativa apenas a síntese. Uma vez total e completamente feitas tais distinções lógicas, se dará a precisão ou exaustividade sintética de um conceito ou a sua total profundidade analítica (AK62). A esse conjunto de considerações, depois de lembrar que os lógicos da escola wolffiana só utilizavam a decomposição pura e simples, Kant acrescenta a distinção entre a operação sintética de "formar um conceito distinto" e a operação analítica de "tornar distinto um conceito" (AK63), pela qual "o conteúdo de meu conhecimento não cresce de modo algum", mas "somente a forma se modifica" (AK64). E, assim, o procedimento analítico opera apenas com a "distinção dos conceitos" - e por isso é o "único de que a Lógica pode se ocupar" -, ao passo que a síntese "faz a distinção dos objetos" (AK64). São, portanto, procedimentos independentes e de horizontes distintos.

O segundo conjunto de considerações que a Lógica traz relativo à oposição em questão diz respeito à distinção entre proposições analíticas e proposições sintéticas (AK111). Embora amplamente conhecida, não é em vão frisar, contudo, o fato de que essa distinção entre os tipos de proposições é irreversível e estanque, de modo que os dois conjuntos de proposições, analíticas e sintéticas, constituem dois mundos separados e incomunicáveis, não havendo passagem, complementaridade ou interferência entre um e outro. Todo juízo analítico será sempre analítico, e todo juízo sintético será sempre sintético. Além disso, o procedimento de compreensão do primeiro se faz apenas e se esgota completamente por análise: os juízos analíticos, que poderiam "denominar-se juízos de elucidação", nada acrescentam, por meio do predicado, ao conceito do sujeito, mas apenas "o dividem por desmembramento (Zergliederung) em seus conceitos parciais que já eram (embora confusamente) pensados nele". Os juízos sintéticos, por sua vez, que são "juízos de ampliação", "acrescentam ao conceito do sujeito um predicado que de modo algum era pensado nele nem 
poderia ter sido extraído dele por desmembramento (Zergliederung) algum" (A7/B11). Mesmo com a introdução dos juízos sintéticos a priori, se mantém a distinção entre juízos cuja elucidação ou caráter explicativo se dá por desmembramento ou decomposição e juízos que não podem, em razão de seu caráter ampliativo ou extensivo, ser compreendidos por meio dessa operação, exatamente porque são constituídos por uma operação de natureza sintética (B16). Esse é o caso da matemática e da ciência da natureza, mas não da metafísica (do tipo pensado, nesse momento, por Kant), na medida em que esta última se reduz à análise, isto é, à "mera decomposição de conceitos que residem $a$ priori na razão" (B23). E, portanto, juízos analíticos e juízos sintéticos pertencem a horizontes distintos, não sendo nem complementares nem transitivos entre si: embora formem o conjunto todo dos juízos, eles pertencem a classes distintas, não podem se auxiliar mutuamente nem podem ser vistos como a contraparte um do outro.

O terceiro conjunto de considerações diz respeito às definições analíticas e definições sintéticas e à oposição entre um conceito dado e um conceito feito, algo já presente na distinção entre notas analíticas e notas sintéticas: "As primeiras são definições de um conceito dado, ao passo que as segundas o são de um conceito feito" (AK141). A síntese de tais conceitos feitos é uma "síntese da exposição" (no caso de conteúdos empíricos) ou uma "síntese da construção" ou "por arbítrio" (no caso da matemática). Feitos sinteticamente, portanto, significa não poderem ser oriundos por decomposição (AK141), não poderem ser a reversão da análise, de sorte que a análise não pode desembocar em uma síntese. Por outro lado, "todos os conceitos dados, quer se deem a priori, quer se deem a posteriori, só podem ser definidos por análise", isto é, "por decomposição de conceitos" (AK142). E aqui Kant procede à seguinte consideração:

“Observação. Como nenhuma prova pode dar-nos a certeza de que todas as notas de um conceito dado se esgotaram por 
uma análise completa, devem ser consideradas inseguras todas as definições analíticas" (AK142).

E, embora a insuficiência da análise se refira, aqui, apenas às definições, é permitido generalizar a tese da insuficiência para todos os procedimentos analíticos, na medida em que lidam com a decomposição de notas, com o "fundamento do conhecimento" de um conceito (AK58). É verdade que a série de notas subordinadas, pela qual "uma nota só representa a coisa mediante outra nota", pode ser considerada finita numa direção, pois "detém-se a parte rei, ou do lado dos fundamentos", mas pode sê-lo apenas na pressuposição de ter conquistado um conceito simples, "irresolúvel" (AK59), indecomponível, algo que a análise, entendida como decomposição, parece não poder assegurar, a menos que seja socorrida por uma operação de natureza diferente ${ }^{41}$.

Um último conjunto de considerações diz respeito ao conceito de divisão lógica, termo próximo ao de decomposição. Segundo Kant, "todo conceito contém sob si um multíplice, na medida em que esse multíplice é concordante, mas também na medida em que é diverso". A "divisão lógica" trata da "determinação de um conceito, no que se refere a todos os possíveis contidos sob ele". E, assim, podemos nos elevar "dos conceitos inferiores aos conceitos superiores e podemos descer de novo destes aos inferiores, por divisão" ou por "divisão de membros de uma divisão" (AK147). A divisão se desmembra, portanto, em subdivisões. E, quanto a isso: 1) a subdivisão "pode continuar indefinidamente", embora comparativamente possa ser considerada finita; 2) uma divisão se faz em dois membros (dicotomia) ou em mais de dois (politomia), a primeira sendo relativa a procedimentos lógicos e a segunda, a procedimentos sobre conceitos empíricos, não

${ }^{41}$ Aqui se situa o problema de como a decomposição pode chegar a um elemento simples. Por ela mesma, parece não poder estar segura disso. Entendida como regressão (em sentido forte), ela poderia supô-lo, visto que o composto ou fundamentado pressupõe o simples ou o fundamento (regressão na direção dele). 
podendo "ser ensinada em Lógica" (AK147); 3) a divisão politômica não "dispensa o conhecimento do conteúdo do conceito que se quer dividir" e, portanto, "necessita da intuição"; 4) a dicotomia, de natureza lógica, é realizada sem um princípio sintético e "dispensa o conhecimento do conteúdo do conceito" (AK147) ${ }^{42}$.

Há diferentes conclusões a serem extraídas desses comentários. A primeira diz respeito ao caráter não complementar nem reversível entre procedimentos analíticos e procedimentos sintéticos. Kant não os vê como procedimentos que devam ser feitos um depois do outro ou em dependência entre si. Eles são regidos por princípios distintos, se referem a âmbitos distintos, têm objetivos, direção e extensão distintas: o analítico é vertical e atua por subordinação, enquanto o sintético é horizontal e atua por coordenação; eles são abertos ou fechados por diferentes razões ${ }^{43}$. Eles operam sobre conceitos de natureza distinta: o analítico opera sobre conceitos dados, e o sintético forma os conceitos ${ }^{44}$; o procedimento analítico se limita à análise de conceitos e jamais atinge os objetos, enquanto o procedimento sintético os alcança, os distingue e também os constitui. Os procedimentos

${ }^{42}$ As divisões lógicas (dicotômicas) são em geral abertas ou fechadas por convenção ou por comparação. Além disso, a divisão leva a, no mínimo, dois elementos e não apenas um; e, portanto, pulveriza a unidade de um conceito, ao invés de reunir (sintetizar) a sua compreensão em apenas um. Não há como não lembrar, aqui, de uma passagem da Segunda Meditação (§6), onde Descartes critica a análise de conceitos entendida como divisão ou decomposição: “O que, pois, acreditava eu ser até aqui? Sem dificuldade, pensei que era um homem. Mas o que é um homem? Direi que é um animal racional? Certamente não: pois seria necessário em seguida pesquisar o que é animal e o que é racional e assim, de uma só questão, cairíamos insensivelmente numa infinidade de outras mais difíceis e embaraçosas" (Descartes (1983), 92).

43 Cada um deles enfrenta problemas de completude, o sintético permanecendo aberto em razão de seu campo ampliativo e dos acréscimos possiveis, enquanto o analítico é fechado em direção ao fundamento (pressupondo que possa determiná-lo), mas infinito na direção contrária.

44 Essa é a grande diferença entre análise e síntese na Analítica Transcendental: ao pressupormos a síntese, pressupomos como efetivamente real o conceito, sendo dada a "sintese pura" das representações que nos reportam aos conceitos (A78/B104). Em outras palavras, da síntese chegamos aos conceitos, mas a decomposição de conceitos não nos conduz à síntese. 
analíticos são eminentemente lógicos, atuando sobre conceitos sem acréscimo de conteúdo, contrariamente ao sintético, que pode incorporar novas notas. Por isso, a análise atua apenas sobre a forma e na distinção dos conceitos, e é o único que cabe à lógica. As notas analíticas são, portanto, todas elas conceitos racionais, enquanto as sintéticas podem ser conceitos de experiência (AK59) ou conceitos construídos (AK141) ${ }^{45}$. A distinção kantiana entre juízos analíticos e sintéticos confirma a independência e a incomunicabilidade entre análise e síntese.

Não há como não aproximar o tipo de reflexão acima apresentado àquele dado pela Analítica dos Conceitos, tanto no que diz respeito ao conceito-chave de decomposição quanto às diferentes operações lógicas implementadas. Se aqui é dito que a síntese, por atuar sobre o conteúdo, forma conceitos (contrariamente à análise, que os examina, os decompõe e os divide, mas só os conceitos já dados), na Crítica, isso irá significar que é a síntese (pura) que "formará" os conceitos (puros) do entendimento (A78/B104), embora não se possa entender aqui por "formar" um conceito como um processo anterior ao ato de pensá-lo ${ }^{46}$ : transcendental é exatamente esse horizonte cujos objetos (embora necessários) não são nem independentes do sujeito (não podendo ser nem inatos nem exteriores) nem dependentes dele (não podendo ser constituídos por um sujeito previamente dado), sendo o sujeito nada mais que a unidade que se constitui pela ação de constituição (sintética, antes que analítica) dos conceitos puros. Essa ação não pode ser derivada por um procedimento analítico, entendido como decomposição. Além disso, a decomposição é, no mínimo, dicotômica, diz Kant; e, por isso, jamais poderá nos levar à unidade:

\footnotetext{
45 Parece emergirem aqui alguns elementos do que virá a constituir a distinção kantiana entre análise de conceitos e construção de conceitos, próprias à filosofia e à matemática, respectivamente. Como afirma a Lógica, a "análise dos conceitos" é "assunto da filosofia e é levada ao máximo, especialmente, nas investigações metafísicas" (AK59).

46 Por essa razão, Kant se opõe a toda espécie de inatismo.
} 
ela multiplica as entidades, ao invés de nos conduzir à unidade. E, se acaso certa entidade fosse assumida como unidade, ela seria assumida convencionalmente ou, então, dada por uma síntese pressuposta. Finalmente, se a analítica é decomposição de conceitos dados, ela pressupõe a sua composição correspondente; porém, a formação dos conceitos pela síntese não é uma composição de conceitos, sendo, antes, a cristalização de conceitos indecomponíveis ${ }^{47}$ : os conceitos puros são "formados" por síntese, mas não podem ser decompostos ${ }^{48}$.

\section{IV}

A analítica, do ponto de vista de sua natureza, procede da mesma forma tanto na Lógica quanto na Crítica. A Analítica terá funções

\footnotetext{
47 Aqui mais uma comparação com a filosofia cartesiana. Quando Descartes trata, na Meditação Sexta, da união alma e corpo (do homem propriamente dito), essa união não pode ser encontrada por (de)composição (entre alma e corpo), visto que a união não é uma união componível, embora pressuponha as duas substâncias. A união é uma unidade de ordem distinta, que deve ser pressuposta em razão da existência de fenômenos (as sensações e as paixões) inexplicáveis seja por uma ou outra seja pela junção das duas substâncias: a união é uma espécie de síntese kantiana, cuja decomposição em corpo e alma é sua própria destruição: é uma "unidade complexa" ou um "complexo indecomponível", algo aparentemente contraditório (dentro do paradigma da composição / decomposição).

${ }^{48}$ Um exemplo para terminar: a noção de número. Segundo Kant, “a nossa numeração é uma síntese segundo conceitos (o que é sobretudo evidente nos números elevados), porque se processa segundo um fundamento comum da unidade (o da dezena, por exemplo)", pressuposta na "síntese do diverso" (A78/B104). Entretanto, essa unidade sintética jamais poderia ser encontrada por divisão ou decomposição, no caso de considerarmos uma quantidade em geral (isto é, algo dito ser maior, menor ou igual), mas apenas se considerada aritmeticamente (como um número): uma grandeza geométrica, uma reta, por exemplo, pode ser dividida infinitamente. Assim, na numeração, a divisão estaria pressupondo de antemão a constituição sintética da unidade do múltiplo, ao passo que, feita sobre uma grandeza geométrica, a divisão nos conduz a uma regressão ao infinito; e, portanto, a divisão de uma grandeza ou é dependente da unidade sintética ou é infinita, ou pressupõe a síntese ou é indeterminada. Para os gregos, por exemplo, a noção de grandeza geométrica não incorria no problema da incomensurabilidade da diagonal de um triângulo-retângulo de catetos igual a um, contrariamente a uma compreensão aritmética do caso, a tal ponto que elaboraram uma segunda teoria da proporção, geométrica (no livro V dos Elementos, atribuída a Eudoxo), para além da de natureza aritmética (no livro VII, atribuída a Teeteto), para evitar o problema da incomensurabilidade.
} 
distintas, evidentemente, no âmbito da lógica transcendental (comparada ao da lógica geral), em razão da natureza e objetivos distintos das duas lógicas; entretanto, os procedimentos e as operações efetivadas em ambas são da mesma natureza. Como claramente dito na Lógica, sendo "uma análise da forma do intelecto e da razão", a "Analítica descobre por decomposição (Zergliederung) todas as ações da razão que exercemos em geral ao pensar" (AK16; itálico nosso), e é imitada pela analítica transcendental, que é "a decomposição (Zergliederung) de todo o nosso conhecimento a priori nos elementos do conhecimento puro do entendimento" (A64/B89), cabendo, por sua vez, à analítica dos conceitos "a decomposição (Zergliederung), ainda pouco tentada, da própria faculdade do entendimento, para examinar a possibilidade de conceitos a priori" (A64/B90), confirmando a natureza formal e "conceitual" da analítica, na medida em que ela não é uma decomposição "segundo o conteúdo", mas uma "decomposição da própria faculdade" do entendimento. Segue o último texto na íntegra:

“Por analítica dos conceitos entendo não a análise dos mesmos ou o processo corrente em investigações filosóficas, de decompor, segundo o seu conteúdo, os conceitos que se oferecem e clarificá-los, mas a decomposição, ainda pouco tentada, da própria faculdade do entendimento, para examinar a possibilidade dos conceitos a priori, procurando-os somente no entendimento, como seu lugar de origem, e analisando em geral o uso puro do entendimento [...]. Seguiremos pois os conceitos puros até aos seus primeiros germes e disposições no entendimento humano, onde se encontram preparados, até que, finalmente, por ocasião da experiência, se desenvolvam e, libertos pelo mesmo entendimento das condições empíricas que lhe são inerentes, sejam apresentados em toda a sua pureza" (A65-66/B90-91). 
A noção de decomposição (Zergliederung) aparece em outros lugares da Crítica, e é por vezes traduzida por análise, desmembramento ou mesmo por dissecação, dentre os quais podemos citar, além da própria Analítica, a Introdução à Crítica (a partir do final da seção III até seu final $)^{49}$. Outras noções ou pressuposições parecem se relacionar à de analítica e à de decomposição, tais como as noções (apontadas no início da Analítica Transcendental) de divisão, a distinção entre conceitos elementares e derivados, a noção de interconexão das partes em um sistema ou totalidade (A64-65/B89), bem como a preocupação com a completude e a abrangência total do quadro estabelecido ${ }^{50}$, tendo como pressuposição o entendimento como "unidade subsistente por si mesma e em si mesma suficiente, que nenhum acréscimo do exterior pode aumentar" (A64-65/B89-90).

Essas exigências e pressuposições não deixam, entretanto, de se constituírem como dificuldades à empreitada kantiana. A Analítica dos Conceitos, depois de caracterizar a decomposição como busca dos "conceitos puros até aos seus primeiros germes e disposições no entendimento humano", para que "sejam apresentados em toda a sua pureza", reconhece as "condições empíricas que lhe são inerentes" e o fato de eles serem "desenvolvidos por ocasião da experiência" (A66/ B91). Depois disso, Kant expõe outras duas preocupações fundamentais: a de que "não se poderá nunca determinar com segurança, por esse processo, de certo modo mecânico, quando estará terminada tal

\footnotetext{
49 O termo aparece também na Doutrina Transcendental do Método, na Primeira Seção do Capítulo I, intitulada A Disciplina da Razão no Uso Dogmático (A728-730/B756-758). Outro uso da noção de decomposição aparece na Oitava Seção do Capítulo II do Livro II da Dialética Transcendental, intitulada Princípio regulativo da razão pura com respeito às ideias cosmológicas. Entretanto, nesse caso o termo utilizado por Kant não é "Zergliederung", mas "Dekomposition" (A513-514/B541-542). Kant utiliza também termos como "Auflösung" (resolução) para qualificar a análise (B130).

50 São quatro os pontos importantes a serem considerados pela decomposição, dentre os quais os últimos dois são os que interessam aqui: "3. Que [os conceitos puros] sejam conceitos elementares e sejam bem distintos dos derivados ou dos compostos de conceitos elementares. 4. Que a sua tábua seja completa e abranja totalmente o campo do entendimento puro" (A64/B89).
} 
investigação", e a de que não se poderá confiar em conceitos que, quando "se descobrem ocasionalmente, não apresentam nenhuma ordem nem unidade sistemática" (B 91-92). E, assim, a analítica pode nos conduzir a um processo ad infinitum (como já antevisto pela Lógica) e pode se dar de forma incompleta, desordenada e assistemática, além de ter uma relação nada simples com a estética transcendental (com o contraponto material do conceito) e com "os germes e disposições" dos conceitos puros. São examinadas abaixo algumas dessas tensões.

As primeiras duas seções da Analítica dos Conceitos confirmam a natureza lógica e formal da analítica, como mostram os seus respectivos títulos ("Do uso lógico do entendimento em geral" (A67/B92); "Da função lógica do entendimento nos juízos" (A70/B95; itálico nosso)), de sorte que a lógica transcendental marca efetivamente sua diferença em relação à lógica geral a partir da Seção Terceira (§ 10), como se pode ver pela frequência com que as duas lógicas são comparadas e distinguidas. Pode-se, contudo, perceber uma dificuldade já nessas seções, dificuldade relativa às duas definições de entendimento ou às duas concepções de função, as quais não parecem plenamente equivalentes. Segundo Kant, o entendimento é a faculdade do pensar discursivo, e pensar é a ação de ordenar ou de subsumir conceitos sob um conceito comum. E, assim, os conceitos repousam sobre funções que expressam a unidade presente nessa ação voltada ao ordenamento e à subsunção: "Entendo por função a unidade da ação que consiste em ordenar diversas representações sob uma representação comum" (A69/B93). Por outro lado, o entendimento pode ser representado como faculdade de julgar, na medida em que podemos "reduzir a juízos todas as ações do entendimento", sendo os juízos a expressão dessa unidade: os juízos "são funções da unidade sob nossas representações" (A69/B94). Há, pois, duas noções de unidade e de função, como reconhece o próprio Kant: "Encontram-se, portanto, todas as funções do entendimento, se pudermos expor totalmente as funções da unidade nos juízos" (A69/B94; itálico nosso). Embora não se deseje duvidar dessa tarefa, segundo Kant, 
"perfeitamente exequível" (A69/B94), é preciso assinalar a duplicidade das noções de unidade e de função. Ocorre que as funções da unidade nos juízos parecem pressupor mais coisas do que pressupõem as funções do entendimento de ordenar representações umas sob as outras (A69/ B93), de sorte que o juízo pressupõe uma unidade ausente na relação de subsunção entre conceitos, não havendo transitividade (composição / decomposição) entre subsunção de conceitos e elaboração de juízos: um juízo revela uma unidade que não pode ser encontrada numa analítica dos conceitos ${ }^{51}$. Em um juízo, o entendimento "forma" transcendentalmente novos conceitos, os conceitos puros, inexistentes em suas partes constituintes (reveladas analiticamente) ${ }^{52}$. Em outras palavras, a unidade presente na ação do entendimento de ordenar representações umas sob as outras é uma unidade de natureza lógica, podendo ser dissecada analiticamente, ao passo que a unidade pressuposta pelo juízo (ou, se levada mais adiante, a unidade originária da consciência, dado que o juízo também pode ser dividido quanto à sua forma e à sua matéria) já não pode sê-lo, seja porque, aí, não se pode mais separar (embora talvez abstrair) matéria e forma, seja porque se chegou ao elemento último indecomponível, sempre pressuposto desde sempre por toda ação do entendimento. E, assim, uma posterior separação de elementos nesse nível é a destruição do próprio ato de pensar.

A análise, como diz a Lógica, é uma operação que leva à distinção, divisão e subsunção entre conceitos e nos permite uma definição mais

\footnotetext{
51 Sendo o conceito "uma representação universal ou uma representação do que é comum a vários objetos e, assim, uma representação na medida em que pode estar contida em várias" (AK91), ele mantém uma relação de subsunção tanto "material" (isto é, uma representação de algo comum a vários objetos) quanto "formal" (isto é, uma representação geral ou uma marca comum a várias representações), mas não revela a unidade constituinte de um juízo.

52 A Analítica dos Conceitos parece ser mais uma "Analítica dos Juízos". Embora, em um primeiro momento, as ações do entendimento sobre conceitos possam ser reduzidas a juízos, em um segundo momento, são os juízos que são reconduzidos a conceitos, visto que o que é analisado é o juízo, tendo como pressuposta (e como consequente, embora não por decomposição) a tábua das categorias, os conceitos.
} 
precisa, exaustiva e profunda, bem como a indicação das notas, por meio das quais conhecemos as coisas; o resultado é, sempre, a separação entre os elementos constituintes: a análise separa, divide, mostra os elementos componentes, desfaz a complexidade. A noção de unidade, em um juízo, é uma "unidade complexa", constituída por síntese: como unidade, não pode ser decomposta, embora não seja simples; e Kant reconhece isso quando diz que é preciso "reduzir a juízos todas as ações do entendimento" (A69/B94; itálico nosso), não podendo regredir a decomposição para além da unidade que eles representam. Portanto, analiticamente, a unidade do juízo é simples, mas sinteticamente, não. É uma unidade simples, vista a partir dele e das relações entre juízos; ela é complexa, vista a partir do conceito puro, dado que um juízo o pressupõe: o juízo é uma unidade originária, cuja análise como decomposição é sua própria destruição. Em outras palavras, o juízo é uma relação construída sinteticamente ou uma ligação constituída por um ato de espontaneidade do sujeito (B130), mas que não pode ser decomposta para além de si mesma. Embora haja correspondência entre as funções, a analítica não consegue percorrer, por decomposição, o caminho que vai da tábua dos juízos à tábua das categorias. Isso pode ser traduzido na afirmação de que a analítica, entendida como decomposição, é um procedimento lógico, enquanto a síntese é uma "ação transcendental". E não há passagem do lógico ao transcendental.

A unidade originária, revelada pelo juízo, é complexa também sob esse aspecto: ela tem, necessariamente, matéria e forma, ao contrário da decomposição, que é um procedimento apenas lógico e feito sobre conceitos dados. Com efeito, "nenhum conceito pode ser de origem analítica quanto ao conteúdo" (A77/B 103). Mesmo que, sob a perspectiva transcendental,

"não podemos representar coisa alguma como sendo ligada no objeto se não a tivermos nós ligado previamente 
e também que, entre todas as representações, a ligação é a única que não pode ser dada pelos objetos, mas realizada unicamente pelo próprio sujeito, porque é um ato da sua espontaneidade" (B130),

isso não significa que essa ação de ligar possa ser feita sem objeto: ela não é dada pelo objeto, mas o pressupõe ${ }^{53}$ como polo constituinte, ao mesmo tempo em que é constituída por um sujeito.

A Lógica, em sua definição e caracterização do juízo em geral, ao mesmo tempo em que afirmava a sua unidade fundamental, o caracterizava como constituído de matéria e forma e determinava o escopo da lógica como concernente apenas à forma. Todo juízo, diz ela, "é uma representação da unidade da consciência de diversas representações ou a representação da relação entre elas, na medida em que constituem um conceito" (AK 101) e, enquanto tal, é constituído de matéria e de forma, cada qual determinando um tipo de ligação ou relação com a unidade da consciência. E, da mesma forma que não se ocupou do conteúdo dos conceitos, a lógica não trata da matéria dos juízos, mas apenas da sua "diferença" "no que concerne à sua mera forma" (AK101). A analítica como decomposição, portanto, por mais que examine o juízo, tem como resultado a separação dos elementos formais e materiais, divisão está que pode ser conduzida até a unidade da consciência. Isso nos indica que a unidade originária pode ser empurrada para além dos juízos, até seu limite (a unidade sintética originária da apercepção), sem jamais ser atingida por um procedimento por decomposição. É possível adiar sua pressuposição, mas, mais cedo ou mais tarde, ela deve ser pressuposta sem ter sido vislumbrada ou antevista pela analítica.

53 Como entender essa pressuposição do objeto é uma dificuldade inerente à interpretação do pensamento kantiano. De todo modo, isso não significa pressupor certo conteúdo ou objeto empírico dado, mas as condições da intuição de um objeto em geral. 
Mais acima nos referimos à diferença entre conceitos dados e conceitos feitos. A análise se restringe aos primeiros, e a síntese se refere aos últimos. Embora, na Lógica, Kant, quando trata dos conceitos feitos pela síntese, se refira basicamente aos conceitos empíricos, aqui, ele está envolvido com outra espécie de conceitos. E é essa a grande novidade: evidenciar um conjunto de conceitos, os conceitos puros do entendimento, que não são dados nem no âmbito do sujeito (contrariamente ao inatismo ou ao subjetivismo) nem no âmbito do objeto (contrariamente ao empirismo ingênuo), mas são constitutivos da experiência. E essa novidade é eclipsada por ações do entendimento reveladas pelo que Kant denomina síntese ou ligação.

É verdade que Kant afirma que

“o mesmo entendimento, pois, e isto através dos mesmos atos pelos quais realizou nos conceitos, mediante a unidade analítica, a forma lógica de um juízo, introduz também, mediante a unidade sintética do diverso na intuição em geral, um conteúdo transcendental nas suas representações do diverso" (A79/B105).

Entretanto, ele reconhece textualmente que "a unidade analítica da apercepção só é possível sob o pressuposto de qualquer unidade sintética" (A97/B 133), e indica a "unidade sintética da apercepção" como "princípio supremo de todo o uso do entendimento" (B 136). Além disso, Kant reconhece nessa citação que a unidade analítica diz respeito à forma lógica do juízo, enquanto a unidade sintética trata de um conteúdo transcendental, o que pressupõe a "materialidade" da intuição em geral. Assim, "através das mesmas ações" não pode significar que as ações analíticas e sintéticas sejam idênticas, mas que as mesmas ações do entendimento podem ser examinadas tanto analiticamente (apenas logicamente) quanto sinteticamente (transcendentalmente), sendo a primeira resultado da abstração de um aspecto da segunda. 
Retomemos mais longamente alguns trechos da Seção Terceira (§ 10). Afirma Kant nessa seção ${ }^{54}$ :

"A lógica geral abstrai, como repetidas vezes dissemos, de todo o conteúdo do conhecimento e espera que, por outra via, seja ela qual for, sejam dadas representações para as transformar em conceitos, o que se processa analiticamente. Em contrapartida, a lógica transcendental defronta-se com um diverso da sensibilidade a priori, que a estética / transcendental the fornece, para dar uma matéria aos conceitos puros do entendimento, sem a qual esta lógica seria destituída de conteúdo, portanto completamente vazia. [...] Porém, a espontaneidade do nosso pensamento exige que este diverso seja percorrido, recebido e ligado de determinado modo para que se converta em conhecimento. A este ato dou o nome de síntese" (A76-77/B102).

"Antes de toda a análise das nossas representações, têm estas de ser dadas primeiramente e nenhum conceito pode ser de origem analítica quanto ao conteúdo" (A77/B103).

"A síntese em geral é, como veremos mais adiante, um simples efeito da imaginação, função cega, embora imprescindível, da alma, sem a qual nunca teríamos conhecimento algum, mas da qual muito raramente temos consciência" (A78/B103).

“Diversas representações são reduzidas, analiticamente, a um conceito (questão de que trata a lógica geral). Mas a lógica transcendental ensina-nos a reduzir a conceitos, não as representações, mas a sintese pura das representações" (A78/B104).

"A mesma função, que confere unidade às diversas representações num juízo, dá também unidade à mera síntese de

54 Aqui são fornecidos, em sequência, vários extratos dessa seção, para poderem ser examinados concomitantemente. 
representações diversas numa intuição; tal unidade, expressa de modo geral, designa-se por conceito puro do entendimento. O mesmo entendimento, pois, e isto através dos mesmos atos pelos quais realizou nos conceitos, mediante a unidade analítica, a forma lógica de um juízo, introduz também, mediante a unidade sintética do diverso na intuição em geral, um conteúdo transcendental nas suas representações do diverso; por esse motivo se dá a estas representações o nome de conceitos puros do entendimento, que se referem a priori aos objetos, o que não é do alcance da lógica geral" (A79/B104-105).

O primeiro extrato de texto parece nos indicar que, se a lógica geral recebe de outra via as representações transformadas analiticamente em conceitos, a lógica transcendental, por sua vez, de modo análogo, recebe da estética transcendental o múltiplo da sensibilidade, sem o qual os conceitos puros seriam vazios (e apenas formais). Por outro lado, se a lógica geral pode abstrair do conteúdo, a transcendental já não pode fazê-lo: a analítica lógica, por ser geral, pode se "dar ao capricho" de desprezar o conteúdo ${ }^{55}$, ao passo que a transcendental precisa mostrar sua real necessidade e efetividade; caso contrário, ela poderia ser apenas uma fantasia ou mesmo nem se dar a conhecer. E isso denuncia, em terceiro lugar, a presença necessária da síntese, algo confirmado pelo segundo extrato: a síntese é necessária, visto que a análise, não atuando senão sobre conceitos (ela é uma analítica de conceitos), não põe conteúdo ou objeto algum. Além disso, a síntese nos remete a uma instância exterior - cega, e da qual somos em geral inconscientes -, o que mostra que ela não pode ser atingida diretamente pela análise (entendida como decomposição), mas apenas

55 Em outras palavras, a lógica geral não pode extraviar-se por ocasião do exame de algo que possa cair fora dela mesma, pois tudo o que ela pensar já estará automaticamente lhe pertencendo. 
pressuposta por ela: a análise chega às portas da síntese, diante da qual se detém, pressupondo-a como já feita ${ }^{56}$. E, se não é afirmada, aqui, claramente uma primazia da síntese, mais adiante Kant o fará, tanto da síntese em geral" 57 (B130) quanto da "unidade sintética originária" (§16, em especial).

Se isso é assim, então é possível questionar a autonomia do entendimento e se perguntar até que ponto ele é uma "unidade autossuficiente" (A65/B 89-90). O que o entendimento realiza autonomamente e, como tal, possa ser dito ser uma faculdade em si mesmo? A analítica dos conceitos dá conta apenas dos conceitos, uma das dimensões das representações cognitivas, mas não do objeto presente nesse conceito. Se seus objetivos fossem os de uma analítica lógica, isso seria aceitável, mas não parece sê-lo de uma analítica transcendental e de uma verdadeira lógica da verdade. O problema parece ser similar ao problema do paralelismo entre matéria e forma: elas são dimensões distintas e independentes, embora confluentes para originar uma entidade; uma, portanto, não denuncia a outra, a menos que se suponha dada a "realidade" da entidade. Ou, então, aqui aparece o que se poderia denominar o "problema kantiano das paralelas": análise (lógica) e síntese (transcendental) são como que duas retas paralelas, coplanares, mas que, como tais, jamais se encontram. Elas são solidárias, mas seu paralelismo jamais permite que uma denuncie a outra. Isso é válido pelo menos para a análise: ela não denuncia a síntese.

A decomposição operada pela analítica atomiza os componentes descomprometendo-os de sua participação na totalidade. Isso se dá pela natureza lógica e formal assumida pela analítica transcendental,

56 Com efeito, dirá Kant mais adiante, "não podemos nos representar nada ligado no objeto sem o termos nós mesmos ligado antes", pois, com efeito, "onde o entendimento nada ligou não pode também decompor nada" (B130).

57 “Aqui facilmente nos apercebemos que este ato [a síntese] deve ser originariamente único e deverá ser igualmente válido para toda a ligação e que a decomposição em elementos (a análise), que parece ser o seu contrário, sempre afinal a pressupõe" (B130). 
embora não pudesse sê-lo, dada a pretensão da tarefa transcendental. O que ocorre é que a análise e a síntese no âmbito transcendental mantêm as características da análise e da síntese lógicas. Com efeito, na Analítica Transcendental, a síntese se refere aos objetos e a análise aos conceitos, como afirma a Lógica: "A síntese faz a distinção dos objetos; a análise faz a distinção dos conceitos". Por isso, continua Kant, "a análise não pode ir tão longe a ponto de fazer que, no final, o próprio objeto desapareça" (AK64). A análise faz desaparecer conceitos: visto que nela "o todo precede as partes", esse todo é decomposto e desaparece, fazendo emergir as partes. Mas ela faz isso com conceitos e não com objetos, pois não opera sobre objetos: por isso ela "não pode ir tão longe" e não pode "fazer que, no final, o próprio objeto desapareça". Por sua vez, a síntese (onde "as partes precedem o todo" (AK64)) opera sobre objetos e faz a distinção entre objetos. A oposição entre análise e síntese não é apenas em termos de movimentos contrários (decomposição, composição; ir do todo às partes e das partes ao todo), mas de operar sobre horizontes distintos, conceitos e objetos dos conceitos, o que faz que elas jamais se cruzem: daí, seu paralelismo, sem capacidade de denúncia recíproca (pelo menos no caso da análise).

Aqui cabe uma observação relativa à distinção entre analítica e dialética. Na Lógica, a dialética é entendida como "resultado de um mero abuso" (AK16) da analítica, em razão da presença inadequada de conteúdo; na Crítica, a dialética é uma lógica da aparência por ausência de conteúdo. E, embora a operação dialética da razão seja entendida como ultrapassagem de seus próprios limites, esse desrespeito se dá por razões opostas, em um caso pela presença de conteúdo e em outro pela sua ausência. A diferença entre dialética transcendental e analítica transcendental é a presença necessária da materialidade nesta última e a sua ausência na primeira. E, assim, a Analítica Transcendental não pode ser meramente formal, exatamente porque se distingue da Dialética Transcendental pela presença da materialidade, enquanto esta última a pressupõe ilusoriamente. A lógica transcen- 
dental, portanto, é dialética, não quando é puramente formal, mas quando simula um conteúdo inexistente ou inacessível. O que faz dela ser analítica (e não dialética) é a presença, efetiva e necessariamente, de um conteúdo, um conteúdo, entretanto, que vem de fora dela, da Estética Transcendental. Essa é também a diferença fundamental entre as duas Doutrinas dos Elementos, a da Lógica e a da Crítica, como já dissemos: a Analítica Transcendental (portanto, a Lógica Transcendental) pressupõe, para ser o que ela é, elementos provenientes de fora dela. Essa dificuldade pode também ser examinada na perspectiva da autonomia e da autossuficiência do entendimento e de suas operações, na medida em que o entendimento parece ser o que é apenas na medida em que tiver como contraponto o conteúdo dado pela faculdade da sensibilidade. A primazia da unidade sintética sobre a unidade analítica denuncia que a lógica transcendental parece não poder se fazer sem seu contraponto material (os elementos fornecidos pela estética transcendental): a lógica transcendental é diferente da lógica geral, mas indica, ainda, se pautar por ela e por seu caráter formal.

\section{V}

A dedução transcendental parece responder ao problema do paralelismo entre análise e síntese, e sua necessidade, uma confissão do problema ${ }^{58}$. Mais difícil do que isso é a Lógica Transcendental dar conta da tese da autonomia do entendimento frente ao fato de que há elementos que lhe escapam: a Doutrina Transcendental dos Elementos toda ela envolvida na tarefa transcendental - é mais ampla que a Lógica

58 Descartes resolveu um problema semelhante por meio da admissão da intuição: por meio da apreensão de algo simples, autoevidente e, ao mesmo tempo, constituído de matéria e forma. A indissociabilidade, na intuição cartesiana, entre matéria e forma dispensa a síntese; a autoevidência do ato intuitivo dispensa a necessidade de uma prova; a analítica entendida como regressão, mais do que decomposição, vai ao encontro da síntese, mas que é supérflua, pelas razões já citadas. 
Transcendental: enquanto lógica (a exemplo da formal), ela poderia dispensar o conteúdo; como transcendental, ele teria que abarcá-lo necessariamente. São os resquícios da inspiração lógica da Crítica.

\section{Bibliografia}

ARISTÓteles (1987): Ética a Nicômaco. São Paulo, Nova Cultural. (Os Pensadores). ARISTÓTELES (1992-1995): Organon. Paris, Vrin. Tradução e notas de J. Tricot.

ARNAUlD, Antoine - Nicole, Pierre (1992): La logique ou l'art de penser. Paris, Gallimard. Notas e posfácio de Charles Jourdain.

BERTI, Enrico (2010): Novos Estudos Aristotélicos I: Epistemologia, Lógica e Dialética. São Paulo, Loyola.

CAYGILL, Howard (2000): Dicionário Kant. Rio de Janeiro, Zahar.

DESCARTES, René (1983): Discurso do Método; Meditações. 3. ed. São Paulo, Abril Cultural. (Os Pensadores).

EUCLIDES (1956): The Thirteen Books of Euclid's Elements. 3 vol. New York, Dover. Tradução de Thomas L. Heath.

FREULER, Léo (1992): Kant et la métaphysique spéculative. Paris, Vrin.

HINTIKKA, Jaakko - Remes, Unto (1974): The method of analysis. Dordretch, Publishing Company.

HINTIKKA, Jaakko (1973): Logic, language-games and information: kantian themes in the philosophy of logic. Oxford, Clarendon Press.

KANT, Immanuel (1980): Crítica da Razão Pura. São Paulo, Abril Cultural. (Os Pensadores). Tradução de Valério Rohden e Udo Bladur Moosburger.

KANT, Immanuel (1992): Lógica. Rio de Janeiro, Tempo Brasileiro. Tradução de Guido Antônio de Almeida.

KANT, Immanuel (2001): Crítica da Razão Pura. 5. ed. Lisboa, Calouste Gulbenkian. Tradução de Manuel Pinto dos Santos e Alexandre Fradique Morujão.

KANT, Immanuel (2003): Manual dos Cursos de Lógica Geral. 2. ed. Campinas, SP, Editora da Unicamp; Uberlândia, MG, Edufu. Tradução de Fausto Castilho.

LOPARIC, Zeljko (1982): The Methods of Analysis in Kant's Speculative Philosophy. Campinas, SP, Unicamp. (Tese de livre-docência).

LOPARIC, Zeljko (2000): A Semântica Transcendental de Kant. Campinas, SP, Centro de Lógica, Epistemologia e Filosofia da Ciência.

SCHOPENHAUER, Arthur (1988): Crítica da Filosofia Kantiana. São Paulo, Nova Cultural. (Os Pensadores).

TIMMERMANS, Benoît (1995): La résolution des problèmes de Descartes à Kant. Paris, PUF. 
